\title{
Prevalence of Geriatric Dermatoses Among Elderly Patients Treated at the Dermatology Outpatient Clinic in Eskisehir, Turkey
}

(1) Hamza Yıldız

\begin{abstract}
Objective: The aim of this study is to determine the prevalence of skin diseases among geriatric patients in Eskisehir, Turkey.

Methods: This is a retrospective, cross-sectional study. The medical records from the outpatient clinics of dermatology were retrospectively assessed. Patients who were over 65 years old and attended the dermatology outpatient's clinic between January 2017 and December 2017 were included in the study.
\end{abstract}

Results: A total of 7,722 patients were included in the study: 3,666 (47.5\%) patients were male, and 4,056 (52.5\%) patients were female. The ten most frequent diagnoses and their prevalence were the following: contact dermatitis (I5.2\%), xerosis (I3.8\%), pruritus (II.2\%), seborrheic keratosis $(5.8 \%)$, onychomycosis $(5.3 \%)$, seborrheic dermatitis $(5.2 \%)$, tinea pedis (5.2\%), corn and callus (4.6\%), urticaria (4.0\%), actinic keratosis (3.0\%), and pyoderma (3.0\%).

Conclusion: Most of these geriatric skin diseases are preventable or treatable. Raising the general level of awareness is important about these common geriatric dermatoses. Further epidemiological studies are needed to reveal the prevalence of geriatric skin diseases.

\section{INTRODUCTION}

The size and the ratio of the elderly population have been increasing in Turkey just like in other developed and developing countries. It is not surprising that the aging rate of the population will steadily increase in the near future. ${ }^{[1-3]} \mathrm{It}$ has been estimated that the geriatric population will reach $10.2 \%$ in Turkey in 2020. ${ }^{[2]}$ Elderly patients over 65 years of age are an important part of dermatology outpatient clinics. However, there are limited studies on the prevalence and the age and gender distribution of skin diseases in the elderly population.

During aging, functional and structural changes in the skin are observed. Due to these changes, skin disorders are more commonly seen in the elderly population. Moreover, the prevalence of skin diseases in the elderly is different than the prevalence in children and adult populations depending on these factors. ${ }^{[2,3]}$ The prevalence of skin diseases in geriatric patients is very important in planning preventive and therapeutic health care services. Information on the prevalence of skin disorders in geriatric patients is limited. This research article is, to the best of our knowledge, the first prevalence study in the geriatric patients in Eskisehir, Turkey. Thus, we aimed to clarify the prevalence of skin disorders among geriatric patients in Eskisehir, Turkey.

\section{MATERIAL AND METHODS}

This is a cross-sectional retrospective study. The medical records from the outpatient clinics of dermatology were retrospectively assessed. Elderly patients who attended the dermatology outpatient clinics between January 2017 and December 2017 were included in the study.

This was a retrospective study. Therefore, no ethics committee approval was required. Written informed consent could not be obtained from the patients due to a retrospective design of the study.

The exclusion criteria were age $<65$ years, patients with inadequate data, or patients without a definite diagnosis. To find an accurate prevalence, only patients attending the clinic for the first time were included in the study, and repeat referrals were excluded from the study as previous studies. ${ }^{[1,3-6]}$ Patient 65 years old and older were included into study.

A total of 30,001 applications were recorded at the dermatology outpatient clinic. Of the 30,00I patients, 7,722 (25.7\%) were new geriatric patients who were 65 years old and older.

The patients were divided into three groups according to age as follows: the 65-74 age group (Group I), the 75-84 
age group (Group II), and the over-85 age group (Group III).

The patients were diagnosed based on clinical features and an anamnesis, and the diagnosis was confirmed by a skin biopsy or laboratory tests (e.g., fungal direct examination) when indicated. The International Classification of Diseases (ICD-I0) was used to classify the diagnoses.

Statistical analyses were carried out using the Statistical Package for the Social Sciences (SPSS I5.0 Statistical software, SPSS Inc., Chicago, IL, USA). Data were presented as percentages. The calculated values are given as the mean values \pm standard deviation (SD). The chi-square test was used to compare the inter-group differences and correlations. A p-value $<0.05$ was considered to be statistically significant.

\section{RESULTS}

Of 7,722 patients, 3,666 (47.5\%) were male, and 4,056 (52.5\%) were female. The mean age of the patients was $72.82 \pm 6.22$ years (age range, $65-101$ years). The mean age of the female patients was $73.15 \pm 6.45$ years (age range, $65-95$ years). In the male patients, it was $72.53 \pm 6.01$ years (age range, 65-101 years). The male-to-female ratio was 0.90 . There was statistically no significant difference between gender and age $(p=0.896)$.

Of 7,722 patients, 5,094 (65.9\%) were in Group I, 2,262 (29.9\%) were in Group II, and 366 (4.7\%) were in Group III.

Of 7,722 patients, I,536 (19.9\%) patients were diagnosed with more than one skin disease. A total of II 3 skin diseases were recorded.

The ten most frequent diagnoses in the elderly patients and their prevalence were contact dermatitis $(n=1380$, $15.2 \%)$; xerosis $(n=1254,13.8 \%)$; pruritus $(n=1014$, II.2\%); seborrheic keratosis ( $n=522,5.8 \%)$; onychomycosis $(n=480,5.3 \%)$; seborrheic dermatitis $(n=468,5.2 \%)$; tinea pedis $(n=468,5.2 \%)$; corn and callus $(n=420,4.6 \%)$; urticaria $(n=360,4.0 \%)$; actinic keratosis $(n=276,3.0 \%)$; and pyoderma $(n=270,3.0 \%)$. The age distribution of the most common 20 skin diseases according to gender is presented in Table I.

The most frequent types of eczematous dermatitis $(n=2049,26.5 \%)$ were contact dermatitis $(n=1380,15.2 \%)$; seborrheic dermatitis $(n=468,5.8 \%)$; nummular dermatitis $(n=78,1.0 \%)$; lichen simplex chronicus $(n=120,1.3 \%)$; and atopic dermatitis $(n=3,0.03 \%)$.

The commonly seen fungal infections $(n=1184,15.3 \%)$ were onychomycosis $(n=480,5.3 \%)$; tinea pedis $(n=68$, $5.2 \%)$; intertrigo $(n=162,2.1 \%)$; tinea cruris $(n=25,0.3 \%)$; pityriasis versicolor $(n=24,0.3 \%)$; tinea corporis $(n=13$, $0.2 \%)$; and candidiasis $(n=12,0.2 \%)$.

The most frequent viral infections $(n=468,6.0 \%)$ were herpes zoster $(n=252,2.8 \%)$; warts $(n=180,2.0 \%)$; and herpes simplex virus infection $(n=36,0.5 \%)$.
Table I. The distribution of the most common 20 diseases according to gender

\begin{tabular}{|c|c|c|c|c|c|c|c|}
\hline \multirow[t]{3}{*}{ No } & \multirow[t]{3}{*}{ Disease } & \multicolumn{6}{|c|}{ Gender } \\
\hline & & \multicolumn{2}{|c|}{ Male } & \multicolumn{2}{|c|}{ Female } & \multicolumn{2}{|c|}{ Total } \\
\hline & & $\mathbf{n}$ & $\%$ & $\mathbf{n}$ & $\%$ & $\mathbf{n}$ & $\%$ \\
\hline \multirow[t]{2}{*}{1} & Contact & & & & & & \\
\hline & dermatitis & 783 & 8.6 & 587 & 6.5 & 1380 & 15.2 \\
\hline 2 & Xerosis & 211 & 2.3 & 1043 & 11.5 & 1254 & 13.8 \\
\hline 3 & Pruritus & 456 & 5.0 & 558 & 6.2 & 1014 & 11.2 \\
\hline \multirow[t]{2}{*}{4} & Seborrhoeic & & & & & & \\
\hline & keratosis & 217 & 2.4 & 305 & 3.4 & 522 & 5.8 \\
\hline 5 & Onychomycosis & 247 & 2.7 & 233 & 2.6 & 480 & 5.3 \\
\hline \multirow[t]{2}{*}{6} & Seborrheic & & & & & & \\
\hline & dermatitis & 265 & 2.9 & 203 & 2.2 & 468 & 5.2 \\
\hline 7 & Tinea pedis & 247 & 2.7 & 221 & 2.4 & 468 & 5.2 \\
\hline 8 & Corn and callus & 197 & 2.2 & 223 & 2.5 & 420 & 4.6 \\
\hline 9 & Urticaria & 169 & 1.9 & 191 & 2.1 & 360 & 4.0 \\
\hline 10 & Actinic keratosis & 123 & 1.4 & 153 & 1.7 & 276 & 3.0 \\
\hline II & Pyoderma & $13 \mid$ & 1.4 & 139 & 1.5 & 270 & 3.0 \\
\hline 12 & Herpes zoster & 78 & 0.9 & 114 & 1.3 & 252 & 2.8 \\
\hline 13 & Psoriasis vulgaris & 67 & 0.7 & 143 & 1.6 & 210 & 2.3 \\
\hline 14 & Rosacea & 48 & 0.5 & 96 & I.I & 192 & 2.1 \\
\hline 15 & Viral warts & 103 & I.I & 77 & 0.9 & 180 & 2.0 \\
\hline 16 & Intertrigo & 78 & 0.9 & 84 & 0.9 & 162 & 1.8 \\
\hline \multirow[t]{2}{*}{17} & Lichen simplex & & & & & & \\
\hline & chronicus & 54 & 0.6 & 66 & 0.7 & 120 & 1.3 \\
\hline 18 & Melanocytic naevi & 24 & 0.3 & 90 & 1.0 & 114 & 1.3 \\
\hline 19 & Impetigo & 36 & 0.4 & 66 & 0.7 & 102 & I.I \\
\hline 20 & Nummular eczema & 54 & 0.6 & 24 & 0.3 & 78 & 0.9 \\
\hline
\end{tabular}

The frequently seen bacterial infections $(n=461,5.9 \%)$ were pyoderma $(n=270,3.0 \%)$; impetigo $(n=102,1.3 \%)$; cellulitis $(n=72,0.9 \%)$; and erythrasma $(n=17,0.2 \%)$.

There were statistically significant differences between females and males for rosacea and urticaria $(p<0.05$ for all). Males showed a greater susceptibility to xerosis and rosacea. There was no statistically significant difference for other skin diseases ( $p>0.05$ for all).

The distribution (\%) of skin diseases was similar in the three groups, except for a higher percentage of contact dermatitis, callus, and seborrheic dermatitis in Group I $(18.5 \%, 6.6 \%$, and $6.2 \%$, respectively) than in Group II ( $2.4 \%, 0.6 \%$, and $0.8 \%$, respectively), and Group III (I $14.8 \%$, $3.6 \%$, and $4.9 \%$, respectively). The proportion of actinic keratosis was higher in Group III (4.9\%) than in Group I and Group II (3.2\% and $0.8 \%$, respectively). The percentage of pruritus was $11.6 \%$ in Group I, $3.2 \%$ in Group II, and $19.7 \%$ in Group III.

There were some differences in the prevalence of the commonly encountered skin diseases among the age groups.

I) Among 5,094 cases, in Group I, the top 10 skin disorders were, in the descending order of prevalence, contact dermatitis $(n=941,12.2 \%)$; xerosis $(n=827,10.7 \%)$; pruritus 
Table 2. Age distribution of the most common 10 skin diseases

\begin{tabular}{|c|c|c|c|c|c|c|c|c|}
\hline \multirow[t]{3}{*}{ No } & \multirow[t]{3}{*}{ Disease } & \multicolumn{6}{|c|}{ Age groups } & \multirow[t]{3}{*}{ Total } \\
\hline & & \multicolumn{2}{|c|}{$\begin{array}{c}\text { Group I } \\
\text { (65-74 year) } \\
n=5.094\end{array}$} & \multicolumn{2}{|c|}{$\begin{array}{c}\text { Group II } \\
\text { (75-84 year) } \\
n=2.262\end{array}$} & \multicolumn{2}{|c|}{$\begin{array}{c}\text { Group III } \\
\text { (>85 year) } \\
n=366\end{array}$} & \\
\hline & & $\mathbf{n}$ & $\%$ & $\mathbf{n}$ & $\%$ & $\mathbf{n}$ & $\%$ & \\
\hline 1 & Contact dermatitis & 941 & 10.4 & 385 & 4.3 & 54 & 0.6 & 1380 \\
\hline 2 & Xerosis & 827 & 9.1 & 374 & 4.1 & 53 & 0.6 & 1254 \\
\hline 3 & Pruritus & 589 & 6.5 & 353 & 3.9 & 72 & 0.8 & 1014 \\
\hline 4 & Seborrheic keratosis & 336 & 3.7 & 119 & 1.3 & 31 & 0.3 & 522 \\
\hline 5 & Onychomycosis & 323 & 3.6 & 144 & 1.6 & 13 & 0.1 & 480 \\
\hline 6 & Seborrheic dermatitis & 317 & 3.5 & 123 & 1.4 & 18 & 0.2 & 468 \\
\hline 7 & Tinea pedis & 275 & 3.0 & 174 & 1.9 & 19 & 0.2 & 468 \\
\hline 8 & Corn and callus & 336 & 3.7 & 71 & 0.8 & 13 & 0.1 & 420 \\
\hline 9 & Urticaria & 241 & 2.7 & 83 & 0.9 & 36 & 0.4 & 360 \\
\hline 10 & Actinic keratosis & 163 & 1.8 & 95 & 1.0 & 18 & 0.2 & 276 \\
\hline
\end{tabular}

$(n=589,7.6 \%)$; corn and callus $(n=336,4.4 \%)$; seborrheic keratosis $(n=336,4.4 \%)$; onychomycosis $(n=323,4.2 \%)$; seborrheic dermatitis $(n=317,4.1 \%)$; tinea pedis $(n=275$, $3.6 \%)$; urticaria $(n=241,3.1 \%)$; and psoriasis $(n=179,2.3 \%)$.

II) In Group II ( $n=2,262,29.3 \%)$, contact dermatitis ( $n=385$, $4.9 \%$ ) was the most prevalent dermatosis, followed by xerosis $(n=374,4.8 \%)$; pruritus $(n=353,4.5 \%)$; pyoderma $(n=270,3.5 \%)$; tinea pedis $(n=174,2.3 \%)$; onychomycosis $(n=144,1.9 \%)$; seborrheic dermatitis $(n=123,1.6 \%)$; seborrheic keratosis $(n=119,1.5 \%)$; actinic keratosis $(n=95$, I. $2 \%)$; and urticaria $(n=83,1.1 \%)$.

III) In Group III ( $n=366)$, the most frequent diagnoses were pruritus $(n=72,0.9 \%)$; contact dermatitis $(n=54,0.7 \%)$; xerosis $(n=53,0.7 \%)$; urticaria $(n=36,0.5 \%)$; seborrheic keratosis $(n=31,0.4 \%)$; tinea pedis $(n=19,0.2 \%)$; actinic keratosis $(n=18,0.2 \%)$; seborrheic dermatitis $(n=18,0.2 \%)$; corn and callus $(n=13,0.2 \%)$; and herpes zoster $(n=12$, $0.2 \%)$.

The rate and frequencies of the geriatric dermatoses in Group I, Group II, and Group III are represented in Table 2.

\section{DISCUSSION}

The size and the ratio of the elderly population have been increasing in Turkey just like in other developed and developing countries. ${ }^{[2,5]}$ In Turkey, according to the State Institution of Statistics, the population is getting older, with a growing percentage of population in the over-65 age group. It has been estimated that the geriatric population will reach $10.2 \%$ in Turkey in 2020 and 20.8\% in 2050, in Turkey. ${ }^{[1]}$

This will result in more elderly patients attending dermatology clinics. ${ }^{[5]}$ The rapid demographic shift has created challenges for the health care system. Elderly patients over 65 years of age are an important part of dermatology outpatient clinics. It is important for health care providers to be aware of the pattern of skin disorders in the elderly. ${ }^{[5]}$
Among elderly, the commonly seen dermatoses and their prevalence are contact dermatitis, xerosis, pruritus, seborrheic keratosis, onychomycosis, seborrheic dermatitis, tinea pedis, corn and callus, urticaria, actinic keratosis, and pyoderma.

Due to the epidermal barrier dysfunction, the elderly population has elevated sensitivity to the allergens and irritants. Thus, contact dermatitis is an important problem in elderly. ${ }^{[3]}$ In our study, the most commonly seen diseases group was eczematous dermatitis (26.5\%), and moreover, the most frequent type of eczematous dermatitis was contact dermatitis (15.2\%). In previous studies, the frequency of dermatitis was $16.3 \%-58.7 \% .^{[2,3,5-8]}$ The percentage of dermatitis was $16.3 \%$ in Adam's study, ${ }^{[8]} 32.7 \%$ in Bilgili's study, ${ }^{[3]} 30.1 \%$ in Polat's study, ${ }^{[5]}$ and $58.7 \%$ in Liao's study. [7] This result corresponds to findings of some similar previous studies in the elderly population.

In our study, contact dermatitis was more common in Group I than Group II and Group III. Contact dermatitis was relatively low in Group II and Group III. It can be explained by a decreased ability to mount a delayed-type hypersensitivity reaction due to an abnormal immune response in the form of reduced Langerhans' cells. ${ }^{[9]}$

In the elderly patients, prurigo can be caused by a variety of dermatological and systemic conditions, but the most frequent cause is xerosis. ${ }^{[10]}$ Dry skin is a common skin problem in the elderly population. It may lead to asteototic eczema, prurigo, and secondary infections. In our study, xerosis ( $13.8 \%$ ) and prurigo (II.2\%) were very common. In previous studies, the prevalence of prurigo was found at a rate of $19.6 \%$ by Polat et al., ${ }^{[6]} 21.2 \%$ in another study by Polat et al., ${ }^{[5]} 8.8 \%$ by Bilgili et al. in Turkey, ${ }^{[3]} 49.6 \%$ by Durai et al. in India, ${ }^{[1]} 22 \%$ by Darjani et al. in Iran, ${ }^{[10]}$ and also Liao et al. $14.2 \%$ in Taiwan. ${ }^{[7]}$ Xerosis was also found at $58.3 \%$ in Taiwan, ${ }^{[7]} \mathrm{I} 1.6 \%$ in Iran, ${ }^{[10]} 18.3 \%$ in Hong Kong, ${ }^{[12]} 29.5 \%$ in Australia, ${ }^{[13]}$ and $5.4 \%^{[3]}$ and $38.8 \%{ }^{[5]}$ in 
Turkey. The frequency of prurigo and xerosis in our study were compatible with these findings.

Fungal and bacterial infections are common in elderly patients. Several factors such as decreased blood flow, impaired immune function, thinning of skin and dryness, associated systemic diseases, epidermal damage to secondary to itching, and decreased personal care, lead to a delay in the healing process. ${ }^{[3,6,9]}$ In our study, the frequency of dermatophytosis and bacterial infections were $15.3 \%$ and $5.9 \%$, respectively.

In previous studies, the prevalence of fungal infection was found at a rate of $5.6 \%$ by Mponda et al. in Tanzania, ${ }^{[14]}$ $8.2 \%$ by Darjani et al. in Iran, ${ }^{[10]} 10.4 \%$ by Bilgili et al. in Turkey, ${ }^{[3]} 11.9 \%$ in the study by Polat et al. in Turkey, ${ }^{[5]}$ $16.4 \%$ by Chan in Hong Kong, ${ }^{[12]} 16.7 \%$ by Polat et al. in Turkey, ${ }^{[6]} 16.9 \%$ by Souissi et al. in Tunisia, ${ }^{[15]}$ and $38 \%$ by Liao et al. in Taiwan. ${ }^{[7]}$ Fungal infections constituted the most commonly observed infectious skin diseases, similar to our study.

Bacterial infection was also shown as $3.5 \%$ by Mponda et al. in Tanzania, ${ }^{[14]} 5.6 \%$ by Polat et al. in Turkey, ${ }^{[5]} 7 \%$ by Bilgili et al. in Turkey, ${ }^{[3]} 7.1 \%$ by Polat et al. in Turkey, ${ }^{[6]}$ and $8.7 \%$ by Souissi et al. in Tunisia. ${ }^{[15]}$ Our result was not different from these results.

Viral infections, especially herpes zoster, appear commonly in the elderly patients, secondary to an impaired immune function. Not surprisingly, the most frequent viral infection $(6.0 \%)$ was herpes zoster $(2.8 \%)$ in our study. Varicella zoster virus becomes latent in the dorsal root ganglion after recovery from chicken pox at a young age. After decline in immunity, varicella zoster virus is reactivated. [9] In the previous studies, the prevalence of viral infection was found at a rate of $1.5 \%$ by Chan in Hong Kong, ${ }^{[12]}$ $2.1 \%$ by Mponda et al. in Tanzania, ${ }^{[14]} 2.8 \%$ by Bilgili et al. in Turkey, ${ }^{[3]} 4.6 \%$ by Polat et al. in Turkey, ${ }^{[6]}$ and $6.8 \%$ by Souissi et al. in Tunisia. ${ }^{[15]}$

Dominant among malignant and premalignant dermatoses was actinic keratosis with a prevalence of $3.0 \%$ in our study. In the previous studies, actinic keratosis had a high prevalence in most studies, ranging from $1.9 \%$ to $25 \%$. The prevalence of actinic keratosis was found with a rate of $1.9 \%$ in the study by Polat et al. in Turkey, ${ }^{[5]}$ with a rate of $7.5 \%$ in the study by Polat et al. in Turkey, ${ }^{[6]}$ with a rate of $22.4 \%$ in the study by Liao et al. in Taiwan, ${ }^{[7]}$ with a rate of $24.3 \%$ in the study by Darjani et al. in Iran, ${ }^{[10]}$ with a rate of $22.3 \%$ in the study by Cvitanović et al. in Croatia, ${ }^{[16]}$ and with a rate of $25 \%$ in the study by Smith et al. in Australia. [13] There were II patients with basal cell carcinoma, three patients with squamous cell carcinoma, and one patient with melanoma. Actinic keratosis is a precursor lesion to squamous cell carcinoma, and lifetime sun exposure is an important risk factor. ${ }^{[10]}$ Management of the condition requires the avoidance of sunlight and use of sunscreens. ${ }^{[9]}$

There are some limitations to our study. We analyzed an electronic database of a secondary referral medical center, and not the general population. Another limitation to our study is the reliance on clinical records and not direct diagnosis.

In conclusion, most of these geriatric skin diseases are preventable or treatable. Raising the general level of awareness is important about these common geriatric dermatoses. Further epidemiological studies are needed to reveal the prevalence of geriatric skin diseases.

\section{Ethics Committee Approval}

This was a retrospective study; therefore, no ethics committee approval was required.

Informed Consent

Retrospective study.

Peer-review

Internally peer-reviewed.

Authorship Contributions

Concept: H.Y.; Design: H.Y.; Data collection \&/or processing: H.Y.; Analysis and/or interpretation: H.Y.; Literature search: H.Y.; Writing: H.Y.; Critical review: H.Y.

Conflict of Interest

None declared.

\section{REFERENCES}

1. Elderly People in Statistics, State Institute of Statistics, Prime Ministry, Republic of Turkey, Nr 16057, 19 March 2014.

2. Yalçin B, Tamer E, Gur G, Oztaş P, Hayran M, Alli N. Prevalence of skin diseases in the elderly: analysis of 4099 geriatric patients. Int J Dermatol 2006;45:672-6. [CrossRef]

3. Bilgili SG, Karadag AS, Ozkol HU, Calka O, Akdeniz N. The prevalence of skin diseases among the geriatric patients in Eastern Turkey. J Pak Med Assoc 2012;62:535-9.

4. Bilgili ME, Yildiz H, Sarici G. Prevalence of skin diseases in a dermatology outpatients clinic in Turkey. A cross-sectional, retrospective study. J Dermatol Case Report 2013;4:108-12. [CrossRef]

5. Polat M, Yalçin B, Calışkan D, Alli N. Complete dermatological examination in the elderly: an exploratory study from an outpatient clinic in Turkey. Gerontology 2009;55:58-63. [CrossRef]

6. Polat M, İlhan MN. Dermatological Complaints of the Elderly Attending a Dermatology Outpatient Clinic in Turkey: A Prospective Study over a One-year Period. Acta Dermatovenerol Croat 2015;23:277-81.

7. Liao YH, Chen KH, Tseng MP, Sun CC. Pattern of skin diseases in a geriatric patient group in Taiwan: a 7-year survey from the outpatient clinic of a university medical center. Dermatology 2001;203:308-13.

8. Adam JE, Reilly $\mathrm{S}$. The prevalence of skin disease in the geriatric age group. Australas J Dermatol 1987;28:72-6. [CrossRef]

9. Jafferany M, Huynh TV, Silverman MA, Zaidi Z. Geriatric dermatoses: a clinical review of skin diseases in an aging population. Int $\mathrm{J}$ Dermatol 2012;51:509-22. [CrossRef]

10. Darjani A, Mohtasham-Amiri Z, Amini KM, Golchai J, SadreEskhevari S, Alizade N. Skin disorders among elder patients in a referral center in Northern Iran (2011). Dermatol Res Pract 2013;2013:193-205. [CrossRef]

11. Durai PC, Thappa DM, Kumari R, Malathi M. Aging in elderly: chronological versus photoaging. Indian J Dermatol 2012;57:343-52.

12. Chan SW. Prevalence of skin problems in elderly homes residents in Hong Kong. Hong Kong J Dermatol Venereol 2006;14:66-70. 
13. Smith DR, Atkinson R, Tang S, Yamagata Z. A survey of skin disease among patients in an Australian nursing home. J Epidemiol 2002;12:336-40. [CrossRef]

14. Mponda K, Masenga J. Skin diseases among elderly patients attending skin clinic at the Regional Dermatology Training Centre, Northern Tanzania: a cross-sectional study. BMC Res Notes 2016;9:119.
15. Souissi A, Zeglaoui F, El Fekih N, Fazaa B, Zouari B, Kamoun MR. Skin diseases in the elderly: amulticentre Tunisian study. Ann Dermatol Venereol 2006;133:231-4. [CrossRef]

16. Cvitanović H, Knežević E, Kuljanac I, Jančić E. Skin disease in a geriatric patients group in outpatient dermatologic clinic Karlovac, Croatia. Coll Antropol 2010;34:247-51.

\section{Eskişehir'deki (Türkiye) Dermatoloji Polikliniğine Başvuran Yaşlı Hastaların Geriatrik Deri Hastalıklarının Prevalansı}

Amaç: Bu çalışmanın amacı Eskişehir'deki geriatrik hastaların deri hastalıkları prevalansını ortaya koymaktır.

Gereç ve Yöntem: Bu araştırma geriye dönük ve kesitsel çalışmadır. Dermatoloji polikliniğine başvuran hastaların kayıtları otomasyon dosya sisteminden geriye dönük olarak analiz edildi. Ocak 2017 ile Aralık 2017 tarihleri arasında dermatoloji polikliniğine başvuran 65 ve üzeri yaştaki geriatrik hastalar çalışmaya dâhil edildi.

Bulgular: Çalışmamıza 3.666'sı (\%47.5) erkek, 4.056'sı (\%52.5) kadın olmak üzere toplam 7.722 hasta alındı. En sık rastlanan on hastalık ve prevalansı sırasıyla şu şekildeydi: Kontakt dermatit (\%।5.2), kserosis (\%।3.8), prurigo (\%। I.2), seboreik keratosis (\%5.8), onikomikoz (\%5.3), seboreik dermatit (\%5.2), tinea pedis (\%5.2), nasır (\%4.6), ürtiker (\%4.0), aktinik keratoz (\%3.0) ve piyoderma (\%3.0).

Sonuç: Yaşılıarda saptanan bu hastalıklar sıklıkla tedavi edilebilir ve önlenebilir hastalıklardır. Bu hastalıklara karşı genel farkındalık düzeyinin artırıması önemlidir. Deri hastalıkları prevalansını ortaya koymak için daha fazla epidemiyolojik çalışmalara ihtiyaç vardır.

Anahtar Sözcükler: Deri hastalıkları; epidemiyoloji; geriatrik dermatoloji; yaşlı. 